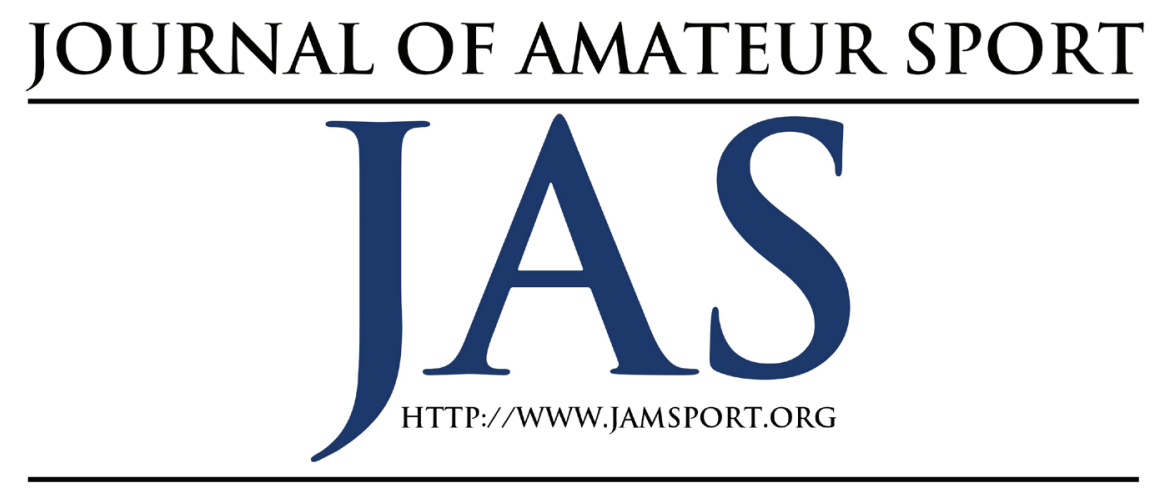

\title{
Female Student-Athletes' Transition out of Collegiate Competition
}

\author{
Allison B. Smith ${ }^{1} \quad$ Robin Hardin ${ }^{2}$ \\ ${ }^{1}$ Virginia Commonwealth University \\ ${ }^{2}$ University of Tennessee
}

\begin{abstract}
Research in the area of athletic identity has grown immensely since it was first brought forward in academic work nearly 20 years ago. The ideas of athletic identity have expanded into the areas of relating to injury and rehabilitation, transitioning into collegiate athletics, transitioning out of collegiate athletics, professional sport careers, and even identity formation through sport. This research explored the experiences of 10 women who had completed their collegiate eligibility and had transitioned out of collegiate competition. Three themes emerged from the semistructured interviews: (a) Identity Crisis, (b) Losses and Gains, and (c) Enjoy the Experience. All the respondents agreed that transition was inevitable, but there were mixed results on whether the transition out of sport was positive or negative. The findings also revealed the struggle of creating an identity outside of sport. The participants indicated establishing new social circles, new routines with fitness, and separating from their sport were challenging. The respondents also believed it was their responsibility to offer advice to future transitioning student-athletes so they could be better prepared for their upcoming transition out of sport.
\end{abstract}

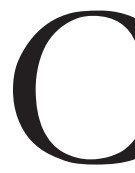

ollegiate student-athletes highly invest in their sport and part of their college choice is likely reflective of the opportunity to participate in sport at the collegiate level (Huffman \& Cooper, 2012). Student-athletes deeply immerse themselves in their sport as some spend nearly 40 hours a week devoted to athletic activities at the NCAA Division I level, despite the 20 hour mandated limit during season from the NCAA (New, 2015). A NCAA 
study found student-athletes spend approximately 34 hours per week on athletic-related activities and 38.5 hours per week on academics (National Collegiate Athletic Association, 2016a). This extra time comes in the form of watching film, additional workouts, or optional practices all in hopes to gain an edge on their opponents. This deep immersion and time investment leads many collegiate student-athletes to not feel competent without their sport and no longer see themselves as having personal, autonomous traits, but instead see themselves with traits solely associated with being a student-athlete (Côté, Baker, \& Abernethy, 2007; Lally, 2007).

This commitment further solidifies their athletic identity or "the degree to which an individual identifies with the athlete role" (Brewer, Van Raalte, \& Linder, 1993, p. 237). Athletic identity can become personal identity where self-esteem and self-worth are tied to sport participation (Kleiber, Mannell, \& Walker, 2011). Collegiate student-athletes narrow their social circles to sport specific stakeholders (i.e., coaches, trainers, teammates) causing their social identity and personal identity to be highly shaped by sports (Côté et al., 2007).

Herein is the issue. Collegiate student-athletes with high athletic identity can experience negative physical and emotional consequences when transitioning out of sport (Lally, 2007; Wylleman, Alfermann, \& Lavallee, 2004). They feel an identity loss when their athletic career is complete and can experience difficul- ty transitioning into a new social environment and into the work place. Their lives have been highly organized around training and competing, and regulated by coaches, and then there is a shift to independently managing their lives (Schwenk, Gorenflo, Dopp, \& Hipple, 2007). It is important these collegiate student-athletes find a way to develop a new identity and progress to the next stage of their adult lives and for many collegiate student-athletes this adjustment to post-sport life takes a longer period of time (Warriner \& Lavallee, 2008). Thus, the purpose of this research is to examine the experience of former female collegiate student-athletes who have recently transitioned out of their collegiate athletic careers. This will provide a foundation to assist in the transition process for collegiate student-athletes, coaches, administrators, family members and other stakeholders.

\section{Transition and Loss of Athletic Identity}

Collegiate athletics is a highly selective realm of competition as only elite student-athletes reach this level. Fewer than $5 \%$ of high school athletes will compete at the NCAA level and even fewer at the Division I - Football Bowl Subdivision (FBS) level, which is considered the best among collegiate sports (National Collegiate Athletic Association, 2016b). This decline in participation opportunities leads to transition out of sport. Those who do compete at the collegiate level have four more years to invest their time and energy into athletics and thus deepen 
their athletic identity. The professional sport opportunities dwindle drastically for the nearly 500,000 student-athletes competing in the NCAA. Thus, the transition out of sport is basically inevitable for collegiate student-athletes except for the most elite.

Transition out of sport occurs either through retirement, injury, or deselection. Deselection takes place when a person is simply not as competent or skilled as other participants and is the most common reason for collegiate student-athletes transition out of sport. Suddenly, these student-athletes are no longer "good enough" and have lost their athletic identity. It has been found that transition due to deselection or injury is the most distressing (Lotysz \& Short, 2004; Wylleman et al., 2004). This process of transitioning out of sport can cause a loss of athletic identity which results in harmful effects holistically to the athlete (i.e., mentally, physically, academically, and socially; Douglas \& Carless, 2009; Lally, 2007; Lotysz \& Short, 2004; Schwenk et al., 2007; Wippert \& Wippert, 2008; Wylleman et al., 2004; Wylleman, Rosier, \& De Knop, 2015).

There is potential for a large sense of loss and a void and athletes can even become delusional because of this intense focus or tunnel vision on athletics when they are no longer able to participate (Lally, 2007; Lotysz \& Short, 2004; Wylleman et al., 2004). The commitment to a team and sport is important and when it ends, there can be emotional issues such as feeling out of control, sense of helplessness, mood swings, depression, anxiety, and even in some extreme cases thoughts of suicide (Lally, 2007; Wylleman et al., 2004). This loss can even cause physical side effects such as loss of appetite, disordered eating, changes to menstrual cycles, weight fluctuation, and insomnia (Blinde \& Stratta, 1993; Wylleman et al., 2004).

Student-athletes may struggle with their changing bodies and regulating nutrition and exercise independently at the conclusion of their athletic careers (Lavallee \& Robinson, 2007). Collegiate student-athletes are provided an optimal nutrition plan (Rodriguez, DiMarco, \& Langley, 2009) due to the concern from coaches and administrators of an increase in risk for disordered eating and misguided nutritional practices due to the nature of competing in elite sport (Cole, Salvaterra, \& Davis, 2005). Collinson and Hockey (2007) advocated that encouraging retiring collegiate student-athletes to continue a fitness routine to provide stability during the transition time period. This solidified routine could negate the loss of self-confidence and sense of distress due to physical changes in their bodies (i.e., decrease muscle mass and increased body fat) that occurs when the transition from sports occur (Warriner \& Lavallee, 2008). Student-athletes who are forced to retire due to injury struggle more because of the focus on the recovery from injury and makes the transition even more challenging (Gilmore, 2008; Kadlcik \& Flemr, 2008; Muscat, 2010). Maladaptive coping mechanisms 
do occur in retired athletes such as alcohol dependence, drug use, increased smoking, and suicide in extreme cases (Douglas \& Carless, 2009; Schwenk et al., 2007; Wippert \& Wippert, 2008; Wylleman et al., 2004; Wylleman, Rosier, \& De Knop, 2015). These unfavorable coping mechanisms are an issue because student-athletes also consume more alcohol, are more likely to binge drink, and experience more drinking related problems than their non-student-athlete peers (Taylor, Ward, \& Hardin, 2017; Wylleman et al., 2004). Forty-four percent of male and $33 \%$ of female collegiate student-athletes participated in excessive drinking (National Collegiate Athletic Association, 2014). Nearly one in four student-athletes also self-reported using social drugs (i.e., marijuana, tobacco, cocaine; National Collegiate Athletic Association, 2014). These factors are important to consider because these issues could become further exacerbated when they are faced with the loss of their athletic career.

Social and professional issues can also occur when transitioning out of sport and losing one's athletic identity. Collegiate student-athletes consistently scored lower in areas pertaining to career maturity, career knowledge, and understanding of a preferred job field which hinders the transition out of sport (Brown, 1993). Collegiate student-athletes can become over-identified with athletics, which causes them to neglect career options and academics (Anderson, 2012; McGillivray, Fearn, \& McIntosch, 2005). Histor- ically, collegiate student-athletes are far behind their non-student-athlete peers when it comes to planning for a career due to their lack of goal setting, career salience, and career decision-making abilities hindered by their sport involvement (Taylor \& Pompas, 1990; Martinus, 2007; Stronach \& Adair, 2010). Anderson (2012) and Lavallee and Robinson (2007) warned that career uncertainty could lead to vulnerability, anxiety, and in some cases unemployment when athletic careers ended.

Collegiate student-athletes have limited opportunities to create a social self and develop relationships outside of sport due to their demanding schedules (Watson, 2003; Watson \& Kissinger, 2007). The ability to develop strong and lasting friendships is an important component of developing self-identity and enhancing the quality of life for a person (Myers \& Sweeney, 2005). Collegiate student-athletes who develop relationships outside of sport have a smoother transition out of sports (Coakley, 2009; Lally, 2007). The demands of athletic participation can lead to feelings of social isolation and an increase in feelings of stress and anxiety (Harris, Altekruse, \& Engels, 2003).

\section{Positive Transition}

Not all transition out of sport is negative, as many student-athletes have a positive transition, transfer the skills from sport to their career, and flourish in their life after sport. Positive transition can be aided when collegiate student-ath- 
letes have positive role models to emulate, especially for African American collegiate student-athletes who participate in the high-profile sports of football and men's basketball (Harrison \& Lampman, 2001; Harrison \& Lawrence, 2002; 2004). Collegiate student-athletes should be provided positive role models, be committed to academic success, and be aware that transition is inevitable (Harrison \& Lawrence, 2003). Harrison and Lawrence (2003) also found career transition was a process and that planning was needed. Having a purposeful and planned career path revolving around the student-athlete's passions also aids in a positive transition (Harrison \& Lawrence, 2004).

Another method for a positive transition is the implementation of transferable skills that translate to career maturity and life after sport for collegiate student-athletes. Collegiate student-athletes can develop high levels of self-worth from sport, and that can aid in academic achievement and in their future professions (Bardick, Bernes, Chorney, Gunn, McKnight, \& Orr, 2009). Retired athletes who had high self-confidence showed positive perspective on their post-sport career and abilities to achieve new career goals (Newell, 2005).

An understanding of transferable skills acquired through sport can also aid in positive transition. These transferable skills include self-motivation, time management, organization, leadership, flexibility, and performing under pressure (Bardick et al., 2009; Stankovich, Meeker, \& Henderson, 2001). Coping mecha- nisms also aid in the positive transition out of sport. These included developing a leisure pursuit to fill the void of the sport, seeking employment in the sport industry, pursuing a fulfilling career outside of the sport profession, and developing a support network (Boixados, Cruz, Judge, \& Torregrosa, 2004; Kadlcik \& Flemr, 2008; Lotysz \& Short, 2004).

There is certainly an adjustment when a person's athletic career ends, but it is not an unmanageable situation. Athletes do adjust to life without their sport and the transition becomes easier the longer the duration away from sport is (Douglas \& Carless, 2009; Lally, 2007; McKenna \& Thomas, 2007; Wippert \& Wippert, 2008). Psychosocial support and programming also have positive influences on the quality of career transition. Support from spouses, families, friends, significant others, coaches, trainers, and teammates have all been linked to a more positive influence on the quality of sport transition (Fernandez, Stephan, \& Fouqereau, 2006; Young, Pearce, Kane, \& Pain, 2006; Wippert \& Wippert, 2008). Organizational support including career planning and discussing the upcoming transition can meditate issues with transition for athletes as well (Harrison \& Lawrence, 2004; Schmid \& Seiler, 2003). Pallarés, Azócar, Torregrosa, Selva, and Ramis (2011) advocated that athletes who follow a convergent (sport is prioritized but is compatible with another job or educational pursuit) or parallel trajectory (sport and education or work are almost equally prioritized) transition 
smoothly and adapt to their new stages of life. In comparison to the linear trajectory (athlete focuses solely on the dedication to his or her sport and develops an almost exclusive athletic identity) that has historically been highly emphasized by coaches and administrators (Azócar, Pérez, Pallarés, \& Torregrosa, 2013; Pallarés et al., 2011; Torregrosa, Ramis, Pallarés, Azócar, \& Selva, 2015).

The United States Olympic Committee (USOC) and the European Union (EU Expert Group) have begun advocating for providing preventive resources in order to allow athletes to balance their athletic careers with education, work, and other life skills (EU Expert Group, 2012; USOC, 2012). This dual career approach allows athletes to avoid situations of forced decisions between athletic careers and long-term transition life care. The NCAA, like the USOC and EU Expert Group, has also made significant strides to provide transition programs for collegiate student-athletes in the past decade. The NCAA has an Innovation and Research Grant Fund which funds research projects in the areas of concern and challenges for collegiate student-athletes such as mental health, transition, long term health and physical activity, and leadership initiatives (National Collegiate Athletic Association, 2018). The NCAA launched a partnership with the National Association of Academic Advisors for Athletics (N4A) to begin daily oversight and operation of programming for collegiate student-athletes in life skills and professional development at the confer- ence and institutional level (National Collegiate Athletic Association, 2016c).

\section{Purpose of the Study}

College student-athletes can face challenges in physical and emotional well-being, career planning and developing social networks when their athletic careers end. Athletic identity is basically the only identity known to them and then they are suddenly at a loss. These student-athletes are not always prepared to transition out of sport as they have devoted most of their time to sport and have spent limited time in academic and social pursuits. Collegiate student-athletes have not developed as much socially as their peers and are not always aware of how to transfer their skills to their professional pursuits (Bardick et al., 2009; Harrison \& Lampman, 2001; Harrison \& Lawrence, 2002; 2004). Transitioning out of sport and the loss of an athletic identity can cause psychological harm (e.g., feeling out of control, sense of helplessness, mood swings, depression, anxiety, and even in some extreme cases thoughts of suicide) physical harm (e.g., loss of appetite, changes to menstrual cycles, weight fluctuation, depression, alcohol use, and insomnia) (Anderson, 2012; Blinde \& Stratta, 1993; Lally, 2007). Thus, it is important to understand this process so support can be given to collegiate student-athletes during this significant time in their lives.

The purpose of this study was to examine experiences of former female collegiate student-athletes who transitioned out of collegiate sport and began a career 
in collegiate athletics administration.

Targeting former female student-athletes who are now working in collegiate athletics administration was warranted for several reasons. First, positive transition can occur when collegiate student-athletes seek employment in another facet of sport (Boixados et al., 2004). Second, women were specifically targeted due to challenges related to women working in collegiate athletics. Women encounter different experiences and challenges working in collegiate athletics than men (Burton, 2015; Smith, Taylor, \& Hardin, 2017, Taylor \& Hardin, 2016). These challenges included homologous reproduction, homophobia, lack of same sex mentors, and an unequal assumption of intelligence and competence causing women to face career mobility issues (Bass, Hardin, \& Taylor, 2015; Kamphoff, 2010; Kilty, 2006, Taylor \& Hardin, 2016). These women are not only transitioning out of their athletic careers, but they are entering a profession where women experience difficulty in regard to career mobility. It is important to understand the experience of women transitioning out of elite competition (e.g., collegiate athletics) so coaches, administrators, teammates, family members, and other stakeholders can assist in this life change. This research also expands on the work of Saxe, Hardin, Taylor, and Pate (2017) that examined the transition experience of female student-athletes during their final years of athletic eligibility. This work examines the transition experience once eligibility has been com- pleted and the participant has moved to the next stage of her life.

\section{Methods}

Semi-structured interviews were used in order to increase awareness of the participants' experiences and inner most thoughts as they pertain to the transition process out of collegiate sport (Corbin $\&$ Straus, 2008). This technique allows for the use of direct quotations from the study participants in order to achieve great detail and insight (Kvale, 1996). Discussion or a free-flowing conversation provides the foundation of interviews, and the use of the open-ended questions provides an opportunity for the participants to express their feelings and perceptions of the transition (Kvale, 1996; Rubin \& Rubin, 1995). Interviews also allow for follow-up questions, which serve to further probe participants and clarify original answers (Kvale, 1996; Rubin \& Rubin, 1995). These semi-structured interviews were conducted on a sample of 10 female graduate assistants working in collegiate athletics that were former collegiate student-athletes.

\section{Sampling}

Institutional Review Board (IRB) approval was received to ensure the integrity of the study. Purposive or specific criterion sampling was used to identity participants. The participants were women who competed in collegiate athletics and held graduate assistant positions in collegiate athletics. Graduate assistants were particularly targeted for this study since they had recently transitioned out 
of their sport and moved into positions within collegiate athletics.

The sample was identified through selecting one NCAA Division I - FBS conference for convenience and to narrow the sample size. The potential participants were then identified by examining the athletic department staff online directories and identifying female graduate assistants. The potential participants were then contacted via e-mail explaining the purpose of the study and requesting participation. Thirty people were initially identified as meeting the criteria for inclusion and were contacted. Ten people responded to the invitation to participate, and all 10 met the criteria for inclusion. All 10 agreed to participant in the study.

Participation in the study included completing an informed consent statement, a demographics questionnaire, and participating in a phone interview. The interviews ranged from 19 minutes to 56 minutes in length with an average of 32 minutes. The female graduate assistants represented multiple areas of the athletic department: coaching, marketing, academics, and athletic training. All 10 graduate assistant participants were single and heterosexual. Eight out of the 10 participants identified as white with two identifying as African-American. All 10 participants had been working in their position for less than two years. Sufficient depth and saturation was achieved with the 10 respondents, so other participants were not recruited (Corbin \& Strauss, 2008; Glaser \& Strauss, 1967; Lindlof \& Taylor, 2011). Additional interviews would add little to the data as common themes began to emerge from the interviews. The participants were assigned pseudonyms in order to protect confidentiality (see Table 1).

\section{Procedure and Analysis}

The interview guide (see Table 2) was used for consistency in the interviews and comprised of questions based on the theoretical framework of athletic identity (Merriam, 2009). This interview guide was constructed to reflect the issues highlighted in the literature surrounding the loss of athletic identity (i.e., sense of loss, emotional and physical hurdles, and possible changes socially). Researchers conducted interviews via telephone and audio recorded them for transcription. Saturation, the point in data collection and analysis where little to no change was identified in coding, was met with 10 participants (Corbin \& Strauss, 2008; Guest, Bunce, \& Johnson, 2006). Interviews were transcribed and formatted for analysis by the principle investigator and then returned to the participants for member-checking (Merriam, 2009). Member-checking is one step in the data validation process (Jones \& Gratton, 2015), and allows participants to review their interview transcript to ensure their responses were accurately transcribed (Andrew, Pedersen, \& McEvoy, 2011).

A constant comparative data analysis method was used for data coding. During constant comparative data analysis one segment of data is compared to another in order to find similarities and differenc- 
Table 1

Demographics

\begin{tabular}{|c|c|c|c|c|c|}
\hline Participant & Age & $\begin{array}{l}\text { Family } \\
\text { Structure }\end{array}$ & $\begin{array}{l}\text { Years in } \\
\text { Position }\end{array}$ & Title & $\begin{array}{c}\text { Collegiate } \\
\text { Sport }\end{array}$ \\
\hline Cathy & 24 & Single & $>1$ & $\begin{array}{l}\text { Academic } \\
\text { Counselor }\end{array}$ & Basketball \\
\hline Donna & 26 & Single & 1 & $\begin{array}{l}\text { Rowing } \\
\text { Administration }\end{array}$ & Swimming \\
\hline Freda & 24 & Single & 1 & Coach & Rowing \\
\hline Irene & 25 & Single & $>1$ & $\begin{array}{l}\text { Academic } \\
\text { Counselor }\end{array}$ & Softball \\
\hline Jessica & 25 & Single & $>1$ & Basketball Manager & Basketball \\
\hline Kara & 24 & Single & $>1$ & $\begin{array}{l}\text { Academic } \\
\text { Counselor }\end{array}$ & Softball \\
\hline Lauren & 22 & Single & $>1$ & Coach & Basketball \\
\hline Melissa & 28 & Single & 1.5 & $\begin{array}{l}\text { Student- } \\
\text { Student-athlete } \\
\text { Development }\end{array}$ & Swimming \\
\hline Norma & 25 & Single & 2.5 & Research Assistant & Basketball \\
\hline Odessa & 24 & Single & 1 & Softball Manager & Softball \\
\hline
\end{tabular}

es (Merriam, 2009). Data are grouped together based on a similar dimension; these groups become the themes of the study.

The primary researcher analyzed the data in two rounds of coding. The first round began by reading through all the transcripts and then coding based on descriptive codes and Invivo coding. Descriptive coding was used to break the transcripts into topics or summarize the basic topic of the passage or quotation (Saldaña, 2013). In comparison, Invivo coding was used to focus on the direct words used by the participants themselves (Saldaña, 2013). These descriptive codes and Invivo codes were then sep- arated or grouped together into initial categories (Boeije, 2010; Charmaz, 2006; Glaser, 1978; Glaser \& Strauss, 1967; Saldaña, 2013; Strauss, 1987; Strauss \& Corbin, 1998). Next, the primary researcher used axial coding as a second round of coding to determine which codes were the dominant and most important, redundant or repetitive codes were collapsed together, and further narrowed categories were created (Saldaña, 2013). In this second round of coding the researcher looked for similarities and differences of experiences across the categories. Themes were created from these categories. 
Table 2

Interview Guide

Questions

1. Are you a former collegiate student-athlete? If so, what sport and position did you play?

2. How long did you play this sport in college? Were you a starter? How many years?

3. How long have you been out of your sport?

4. What has been the biggest adjustment from undergraduate to graduate school?

5. What has been the biggest adjustment from being an student-athlete to no longer being an student-athlete?

6. Can you describe your personal identity and how it was influenced through your collegiate sport? Do you feel that identity is still tied to your sport? If so, how? If not, how come?

7. What has your transition experience out of sport been like for you?

8. If and how has sport changed your nutrition or fitness?

9. If and how has sport changed your consumption of alcohol?

10. If and how has leaving sport changed your social life? Do you have more time now for social activities or hobbies?

11. What advice would you give to current student-student-athletes about transition?

\section{Subjectivity}

The conceptualization for this research peaked from the interest and experience of the primary investigator. The primary investigator played Division II softball and was as a graduate assistant in college athletics after completing her bachelor's degree and transitioning out of the sport of softball. Thus, a subjectivity interview with her research advisor, a pilot on three female graduate assistants at her current institution to ensure clarity of questions, flow, and target any biases or leading questions that could be found in the interview guide prior (Corbin \& Strauss, 2008; Lindlof \&

Journal of Amateur Sport $\quad$ Volume Four, Issue Three $\quad$ Smith and Hardin, 201870 
Taylor, 2011). However, it is also imperative to note that personal experiences as a former student-athlete and transition allow for rapport to be established with the participants and in turn created a rich discussion environment.

\section{Findings}

Three themes emerged from the interviews: (a) Identity Crisis - trouble identifying as a person without their sport and depression that accompanied this crisis (b) Losses and Gains - finding a new social circle and exploring physical well-being on their own terms (c) Enjoy the Experience - advice to future transitioning collegiate student-athletes which included respect the process, keep your contacts, and discover another passion.

\section{Identity Crisis}

Nearly all of the participants discussed the transition out of sport led to a sense of loss or questioning their purpose. They expressed sadness, depression, and feeling lost without their sport. Participants specifically discussed how athletics had always been a part of their lives and they did not feel complete without that identity. Odessa said,

I've been playing sports since I was 5 so not being able to play a sport and compete in a game setting is the hardest. I played three different sports throughout all high school, so it was like 'I was the athlete.'
Kara repeated those thoughts saying, I think it is harder now just because you have played a sport for so long it is hard not to think about that all the time. I think just cause it has only been a year out it is hard and I think because it has always been a part of my life for so long it is hard to separate from that.

Melissa also discussed how to deal with life without competitive sport and whether she would feel the same passion and worth without it. She said,

I went through a very negative phase for about a year and a half. And I'm not even afraid to say that I went through counseling or anything like that. I needed that and I needed to talk to somebody about it all. And that really helped me because it helped me reframe who I was - the person first before I was even a swimmer. My personal identity was my battle within my own brain of how am I going to live up to that again, and feel that high again, you know like how am I going feel that high again, like that was the best feeling of being on top of the world. Like how do I feel that way again? It wasn't really necessarily what anyone else would think of me as much as I was like really hard on myself. That was a hard phase. 
The participants particularly spoke about the feelings of depression, emotional difficulty of leaving sport, and the strain of redefining themselves without sport as the major component. Irene said, I would watch softball on TV and feel a little bit nostalgic. I would think back on the experience I had and some of the regrets I had while I was at school. Things I wish I had done. I am actually trying to separate myself from it. I don't really talk about my softball experience anymore. I think for me I was so tied to it for so long I think I needed to pull away so that I could kind of develop professionally and the career I wanted besides who I was as an athlete.

Freda reiterated these ideas a well. She said,

The transition was definitely hard. It wasn't hard every day but when a big race would come into town (I was) not depressed but really sad that I wasn't racing there anymore. I was sad. It was a really hard transition. When I was still living in New Jersey after I graduated I was a volunteer coach for my old coach and I only went a handful of times because I would get so sad. I had to say, "coach I feel like I kind of need some space because I am not transitioning out well," but when I gave it space I missed it more. It is tough. You want it all or you want nothing.
Donna also felt the hurt of no longer being a student-athlete and discussed how her self-worth was tied to that identity. She said,

Now I have this gapping void and I didn't really have a long-term goal as far as swimming or athletics or really the next step in my life. I didn't really know what was next so I took a long time to figure that out. So those were kind of the two big things. I didn't know how to continue being an student-athlete even though I wanted to be an student-athlete and I didn't really know how to make a plan for other life goals. And it was hard to maintain a positive self-image once I stopped competing because I really didn't know what my self-image was anymore.

\section{Losses and Gains}

Leaving sport also left the participants with major uncertainty about their social circles and physical fitness. Many of the participants discussed how their uncertainty stemmed from their secluded life and schedule as a student-athlete. Odessa said, "[Sport], it's the only experience I've ever had. I don't get much experience doing other stuff other than sport. I didn't have time." Jessica expressed how leaving sport put added pressure to meet new people that was never felt when she was on a team. She said,

When you are on a team you automatically have friends, but when you are no longer on the team you 
no longer have that so it is difficult to figure out how to connect with people since you don't really have basketball in common anymore. You have to find other ways to connect and talk with people. It is just an adjustment I didn't really think about when I was in college.

Cathy echoed these feelings saying, I guess it is hard for me to make friends, when you are part of a team you pretty much have friends they are like your family or sisters. I think now, it is like, 'Oh my gosh, I have to find friends now' and that wasn't an issue before.

Not only was entering new social circles accompanied by feelings of uncertainty, physical fitness was also an issue for some of the participants. Many of the participants expressed that leaving the routine of maintaining physical fitness while a student-athlete added unforeseen challenges. The participants found it difficult to develop personal goals and time for fitness or defining a purpose to their fitness without the same level or intensity of competition. Norma said,

Athletically, I think it is a bit of an adjustment you have to find ways to just stay active and you have to plan gym hours, which I thought I would never have to do. Am I going to work out today? When am I going to work out today?
Kara specifically talked about how she had to change her mind set regarding setting goals for her physical fitness. She stated,

My work ethic or the working out part has subsided a bit but I picked up running so I run halves (marathons) and stuff, but it is weird when you're not training for anything so that is my biggest part or struggle. That is why I have signed up for these because something is an ultimate goal. Because once you work all day and have school once you get home it's not like you want to go workout, and no one is forcing you to so it's easy to be like well I will go tomorrow which I found I have been doing a lot more.

Melissa also mentioned how establishing goals assisted with not having the same competitive outlet that swimming had provided her. She said,

It was hard not having a competitive outlet or anything like that. I learned very quickly, about six months after, that I need to have goals. So I would enter running races and things like that to have a competition to train for because that was something that I needed.

Irene echoed these feelings of a change in work ethic with working out and expressed because it was conditional, mandatory, and regimented for so long it was 
difficult to shift to making those choices priority on her own. She said, But it hasn't been until the past year and a half where I realized it's not about working out for a sport and more for my health. That has been a big transition over the past year and half. It was because I had to run, I had to lift, I had no choice and even when it was a choice it wasn't a choice the non-mandatory type things which I'm sure we all have experienced. So I had the choice now after I was done so I chose not to do anything. It is because it was so regimented absolutely. I have struggled with not having a designated time and what I probably need to do is regiment a time for myself because that's the way I got stuff done. Now I pack clothes. So I packed clothes I have no excuses.

Although the majority of participants discussed how leaving sport resulted in uncertainty, some of the participants embraced this opportunity to explore options that were not present during their athletic careers. Some of the participants viewed leaving sport as an opportunity for exploration that was not available during their undergraduate studies due to their limited schedule with sport. They explained that this gave them a new identity formation in a positive light. This newfound opportunity allowed these former collegiate student-athletes time to explore new hobbies, take control over their own nutrition and physical fitness, and try new sports. Norma said, I am kind of enjoying that part of being able to get out and explore because during undergrad it was class and practice and the team is your life and there is not much outside of that. But now, definitely I am enjoying the extracurricular (activities) and not necessarily things that are linked to sport or school in any way shape, form, or fashion and getting excited to do those things.

Freda expressed the relief and change to her life from being able to exercise and eat based on her own terms, instead of based on her schedule and demands of her coach or team. She said, Now I work out for fun and I eat really healthy and love it and I am so much more comfortable with things and I think my whole lifestyle with nutrition and fitness has changed since I left college. I can just eat what I want and it's mostly healthy. (I) exercise on my own terms. It is more enjoyable now that it has been.

Lastly, Melissa discussed how leaving sport provided her opportunities to explore new sports, and join new social groups outside of the sport she played in college. She said,

I love yoga and I love working out. So I'm a part of two groups. I have my little yoga group and I 
have my friends that I work out with. Like that's social to me, not being a bar on a Friday night. I bond in social activities.

\section{Enjoy the Experience}

All of the respondents felt a need to express advice to collegiate student-athletes that would be facing transitioning out of collegiate sport. They specifically mentioned collegiate student-athletes transitioning out of sport needed to respect the process, keep their contacts from sport, set goals, and discover another passion. For Melissa, she suggested future collegiate student-athletes should be willing to accept changes, challenges, and take initiative early in their career after sport. She said,

Your first job is probably not going to be the thing you fall in love with for the rest of your life. I've moved seven times. I've lived in six different cities. I've had a bunch of different jobs, a bunch of different experiences, and that's what molds you. Just don't be scared to keep continuing to move forward. Just don't stop completely; it doesn't matter, just keep moving forward because each opportunity brings you something. I think a lot of people just sit around and wait until they find something that is going to match what they think they should be doing versus just continuing to move and to keep going forward.
Lauren found that preparation was the key to her success with transitioning out of sport and encouraged collegiate student-athletes to think and plan ahead for their next step. She said, "It's all about thinking ahead and just preparing yourself, setting yourself up for success financially and from an academic standpoint. Just being ready for a real world and what it is that you really want to do with life." Donna echoed Lauren saying, "I would probably tell them to look beyond their sport and really start planning early and start thinking about things that you really want to try and do." Some of the participants discussed preparing for leaving sport meant staying connected with former teammates and coaches and using them as a resource. Kara said, "I feel like just connecting with everyone once you graduate is such a huge part, not to just kind of leave but use them to your advantage." Irene emphasized, "Don't let go of everything. Keep in touch with coaches and people at your school because they are going to be the ones that help you get a job."

Finally, they discussed respecting the process and finding a new passion. Jessica said she would tell collegiate student-athletes facing transition to "find different things that you are interested in and invest time into that." Donna expressed, "I would just say take your time, experience as much as you can, and think about your future not just what you want out of sport but what you want out of life." Cathy followed other participants 
stating that respecting the process is important and discovering your passions,

I think pretty much just respect

the process because it takes a while for you to transfer out, but I am pretty sure if you stay grounded in who you are and what you want and your passions you will be fine.

\section{Discussion}

It is evident that transition out of sport and developing an identity after sport are important issues to former collegiate student-athletes. The responses from the participants in this study show an emphasis needs to be placed on education and preparation of all student-athletes on their entrance into and exit from collegiate sport. There is confusion, uncertainty, and a lack of identity for those leaving collegiate athletics. Sport has been the singular focus of the participants for most of their lives and then all of sudden sport is no longer a part of their life.

The participants in this study discussed how transitioning out of sport left them with a feeling of loss, and specifically the participants in this study mentioned sadness and even self-reported mild depression, which supported the findings of Wylleman et al. (2004) and Lally (2007). Collegiate student-athletes should be educated early in their athletic careers on what transition is, what athletic identity is, and how both components will affect them when leaving sport. This education can occur through role models who were able to succeed after their collegiate careers. Harrison and Lawrence $(2002 ; 2003$; 2004) found that positive transition can be aided when collegiate student-athletes have positive role models to emulate, especially for African-American male collegiate student-athletes in revenue generating sports such as football and basketball. It is essential that collegiate student-athletes understand the full range of the spectrum, both positives and negatives, which they could experience when their competitive athletic experience ends. Collegiate student-athletes need to be made aware that transition will occur, and they should be making preparations for the transition through role models, coaches, and administrators (Bardick et al., 2009; Harrison \& Lawrence, 2002; 2003; 2004). Many institutions are aware of the all-encompassing role athletics play in the lives of student-athletes with a primary focus on athletic development and not necessarily holistic (mind, body, and spirit) development (Huffman, Waller, \& Hardin, 2016; Saxe et al., 2017, Singer, 2005).

There could potentially be changes in their physical and psychological state with the ending of one chapter of their life and starting another (Lally, 2007; Lotysz \& Short, 2004; Wylleman et al., 2004). Coaches and administrators should ensure counselors, psychologists, sport psychologists, and nutritionists readily available to transitioning collegiate student-athletes for assistance with both physical and psychological demands and issues they might encounter and 
insist that collegiate student-athletes are made aware of these services (Boerner, 2011; Fuller, 2014; Lally, 2007; Leonard \& Schimmel, 2016). It is also essential that collegiate student-athletes feel prepared for their upcoming transition into finding employment or an advanced degree program. Collegiate student-athletes should make time to meet with advisors, prepare resumes, cover letters, and experience mock interviews to prepare themselves for the job market once athletics is complete (Stankovich et al., 2001). There should also be an emphasis placed on the development of transferrable skills. Many traits that collegiate student-athletes learn translate well into the job market, such as: leadership, work ethic, self-motivation, and organization (Bardick et al., 2009). Not only did this study support the idea that education in the process of transition, athletic identity, and academic engagement could prepare them for life after sports, but it also found that collegiate student-athletes need more of an emphasis on emotional and social growth.

The respondents identified that their athletic careers limited their ability to develop emotionally and socially and left them in a state of uncertainty or sense of loss when their playing careers ended. The participants particularly mentioned how participating in collegiate athletics did not allow time to develop friendships or to participate in other activities such as spring break, study abroad, opportunities to join professional organizations, professional work experience, or mentorship. Students who are able to experience the norms of college develop the ability to manage emotions, become autonomous, establish an identity, and develop interpersonal relationships (Lally, 2007; Landino, 2013). Collegiate student-athletes are also not often given the opportunity to become independent and care for their needs, develop an identity outside of sports or create and manage relationships outside of a sport context (Landino, 2013). These findings support that collegiate student-athletes are not given the pertinent skills of emotional and social growth due to their schedule and time demands of their sport (Anderson, 2012; Shurts \& Shoffner, 2004).

An emerging finding from this study was the issues related to maintaining fitness and proper nutrition. The respondents discussed uncertainty with how to eat, exercise, and maintain their fitness levels. This uncertainty was related to a lack of education on how to continue these practices once they exited their sport. Research supports that collegiate student-athletes do not have a high level of nutritional knowledge and depend on family, friends, and coaches to supplement this education despite their qualifications (Burns, Schiller, \& Merrick, 2004; Froiland, Koszewski, Hingst, \& Kopecky, 2004; Jacobson, Sobonya, \& Ransome, 2001; Shifflett, Timm, \& Kahanov, 2002). The respondents provided insight on the fear of changing physiques and a desire to maintain their athletic appearance even after their athletic careers end. Many athletes struggle with their self-confi- 
dence, changing body compositions and the ability to regulate nutrition and exercise independently (Collinson \& Hockey, 2007; Lavallee \& Robinson, 2007). A solidified fitness routine has been shown to negate the loss of self-confidence and sense of distress that occurs when the transition from sports occur (Warriner \& Lavallee, 2008). Future research should further explore the education provided to collegiate student-athletes during their careers about exercise and nutrition, and specifically how it relates to transitioning out of sport and maintaining wellness for life. Many times, collegiate student-athletes are told what to do and what to eat but there is little emphasis on the "why" involved in the fitness routine or nutritional plan. This lack of clarity could be changed simply through coaches or trainers explaining the purpose, movement, short and long-term benefit of exercises and foods and through nutrition and fitness courses, seminars, or talks from professionals in the field.

The current findings demonstrate that collegiate student-athletes share similar views about taking advantage of academic and career resources early and often in their collegiate careers (Anderson, 2012; Pate, Stokowski, \& Hardin, 2011). The participants believed through developing new passions, preparing ahead of time for their transition, and exploring opportunities in college, collegiate student-athletes can develop coping mechanisms that aid in positive transition. Their advice revolved around gaining a well-rounded collegiate expe- rience through pursuit of activities and friendships outside of sport. Collegiate student-athletes that obtain experiences outside of sport have a higher chance of positively transitioning out of sport (Boixados et al., 2004).

\section{Limitations}

The purpose of this study was to examine the experiences of women who recently transitioned from the role of collegiate student-athletes to graduate assistants. Saturation was reached with the 10 respondents, but respondents from a different conference or working at different division levels may have different experiences (Corbin \& Strauss, 2008; Glass \& Strauss, 1967; Lindlof \& Taylor, 2011). Telephone interviews could be seen or have been seen as a limitation (Lindloff $\&$ Taylor, 2011). The interviews were conducted via telephone where a participants' body language, expressions, and non-verbal cues could not be observed.

The focus on this study was on women, but future studies should consider utilizing a sample of both men and women in order to make comparisons across genders and or sports. A more exhaustive quantitative study or a mixed-method study including survey of both men and women is also warranted to determine a broader range of experiences as well as the presence of athletic identity and positive or negative perceptions with transition. A quantitative study could capture a larger population of participants, and thus provide more generalizable data and information for collegiate administrators.

Journal of Amateur Sport $\quad$ Volume Four, Issue Three $\quad$ Smith and Hardin, 201878 
It would also be beneficial to examine the perceptions of coaches and administrators to determine their views and insights on collegiate student-athletes transition.

\section{Future Research}

Research should continue to explore the issue of transition as it relates to collegiate student-athletes due to the deeply rooted and unique factors of intertwining athletics, academics, and social life that occur in collegiate sport. Research should focus on collegiate student-athletes at different points past their athletic careers to determine how successful the transition process has been. Follow-up studies on student-athletes at different intervals could possibly provide more details on long term success. Park, Lavallee, and Tod (2013) found that 126 studies have been completed in the past decade focused on student-athlete's career transitions out of sport. However, the focuses of the studies were on self-identity and social support, not on what current athletic departments are doing to address the issue. Knights, Sherry and Ruddock-Hudson (2015) completed a systematic review of transition out of sport literature and found that a gap not only existed on the implementation, but also a lack of research on the positives or the idea of flourishing when leaving sport. Future research should target what information is being distributed to the collegiate student-athletes at the local level (i.e., coaches, administrators, and their athletic departments) and on the idea of succeeding professionally when leaving sport.

\section{Conclusion}

Transition out of sport is inevitable. This occurs at the high school level for most student-athletes as only a small percentage of scholastic sport student-athletes are able to compete at the collegiate level (Estimated Probability of Competing in College Athletics, 2018). For the small minority of student-athletes that compete in collegiate competition, it can become even more even more challenging due to their athletic identity being reinforced (Brewer, Van Raalte, \& Linder, 1993; Côté, 1999; Côté et al., 2007; Côté \& Hay, 2002; Kleiber, Mannell, \& Walker, 2011). Collegiate student-athletes spend an inordinate amount of time devoted to their sport so their athletic identify grows even stronger, thus making the transition out of collegiate sport even more difficult (Watson, 2003; Watson \& Kissinger, 2007). Collegiate sport is a year-round commitment as the pressure to succeed is high. Thus, the idea of being a student-athlete is reinforced on a daily basis. The findings of this study support the concept of the difficulties faced by collegiate student-athletes transitioning out of collegiate sport. There was a sense of loss and confusion by the participants. There was also a feeling of responsibility to assist other collegiate student-athletes as they begin the transition process out of collegiate athletics. This responsibility should be a concern for all stakeholders involved with the collegiate student-ath- 
letes. Coaches, administrators, friends, and family members should be aware of the difficulties in transition, as well as preparation to provide emotional and social support.

\section{References}

Anderson, A. (2012). Helping college student-student-athletes in and out of sport. In Brewer, B., \& Van Raalte, J. (Eds.), Exploring sport and exercise psychology. ( $2^{\text {nd }}$ ed). Washington, DC: American Psychological Association. Andrews, D., Petersen, P., \& McEvoy, C. (2011). Research methods and design in sport management. Champaign, IL: Human Kinetics.

Azócar, F., Pérez, A., Pallarés, S., \& Torregrosa, M. (2013). Foreign football players adaptation to Spanish leagues: Untangling non-normative transitions. In M. Torregrosa, \& A. Vilanova (Eds.), Transitions and strategies in top level sport. Symposium conducted at the XVIII ECSS Annual Congress of European College of Sport Science. Barcelona, Spain.

Bardick, A., Bernes, K., Chorney, D., Gunn, T., McKnight, K., \& Orr, D. (2009). Life after sport: Athletic career transition and transferrable skills. Journal of Excellence, 13, 63-77.

Bass, J., Hardin, R., \& Taylor, E. (2015). The Glass Closet: Perceptions of homosexuality in collegiate sport. Journal of Applied Sport Management, 7(4), 1-36. Blinde, E. M., \& Stratta, T. M. (1993). The "sport career death" of college student-athletes: Involuntary and un- anticipated sport exits. The Journal of Sport Behavior, 15(3), 3-20.

Boeije, H. (2010). Analysis in qualitative research. London: Sage.

Boerner, W.A. (2011). Transitional leadership: Perceptions of interim mid-level student affairs professionals. Dissertation Abstracts International Section A: Humanities and Social Sciences, VOl71(11-A), 3938.

Boixandos, R., Cruz, V., Judge, L., \& Torregrosa, M. (2004). Elite student-athletes' image of retirement: The way to relocation of sport. Psychology of Sport and Exercise, 5, 35-43.

Brewer, B., Van Raatle, J., \& Linder D. (1993). Athletic identity: Hercules muscle or Achilles' heel? International Journal of Sport Psychology, 24, 237-254. Brown, C. (1993). The relationship between role commitment and career development tasks among college student-athletes. (Doctoral Dissertation, University of Missouri, 1993). Dissertation Abstracts International, 54, 864.

Burns, R. D., Schiller, M. A., \& Merrick, K. N. (2004). Intercollegiate student student-athlete use of nutritional supplements and the role of athletic trainers and dietitians in nutritional counseling. Journal of American Dietetic Association, 104, 246-249.

Burton, L. J. (2015). Underrepresentation of women in sport leadership: A review of research. Sport Management Review, 18(2), 155-165.

Charmaz, K. (2006). Constructing grounded theory: A practical guide through qualitative analysis. Thousand Oaks, CA: Sage. 
Coakley, J. J. (2009). Sport in society: Issues and controversies $\left(10^{\text {th }}\right.$ ed.). New York, NY: McGraw-Hill.

Cole, C. R., Salvaterra, G. F., \& Davis, J. E. (2005). Evaluation of dietary practices of National Collegiate Athletic Association Division I football players. Journal of Strength and Conditioning Research, 19, 490-494.

Collinson, J. A., \& Hockey, J. (2007). 'Working out' identity: Distance runners and the management of disrupted identity. Leisure Studies, 26(4), 381-398.

Corbin, J., \& Strauss, A. (2008). Basics of Qualitative Research: Techniques and Procedures for Developing Grounded Theory (3rd ed.). Thousand Oaks, CA: Sage.

Côté, J., Baker, J., \& Abernethy, B. (2007). From play to practice: A developmental framework for the acquisition of expertise in team sport. In J. Starkes and K.A. Ericsson (Eds.), Expert performance in sports: Advances in research on sport expertise, (pp. 89-113). Champaign, IL: Human Kinetics.

Côté, J. (1999). The influence of the family in the development of talent in sport. The Sport Psychologist, 13(4), 395-417.

Côté, J., \& Hay, J. (2002). Children's involvement in sport: A developmental perspective. In M.J. Silva and D.E. Stevens (Eds.), Psychological foundations of sport, (pp. 384-502). Boston, MA: Allyn \& Bacon.

Douglas, K., \& Carless, D. (2009). Abandoning the performance narrative: Two women's stories of transition from professional sport. Journal of Applied Psychology, 21, 213-230. Estimated probability of competing in college athletics. (2018). Retrieved from http://www.ncaa.org/about/resources/research/estimated-probability-competing-college-athletics

EU Expert Group. (2012). EU Guidelines on dual careers of athletes. Brussels.

Fernandez, A., Stephan, Y., \& Fouqereau, E. (2006). Assessing reasons for sports career termination: Development of the athletes' retirement decision inventory (ARDI). Psychology of Sport and Exercise, 7, 407-421.

Froiland, K., Koszewski, W., Hingst, J., \& Kopecky, L. (2004). Nutritional supplement use among college student-athletes and their sources of information. International Journal of Sport Nutrition and Exercise Metabolism, 14, 104-120.

Fuller, R. D. (2014). Transition experiences out of intercollegiate athletics: A Meta-Synthesis. Qualitative Report, 19(46), 1-15.

Gilmore, O. (2008). Leaving competitive sport: Scotish female athletes' experiences of sport career transitions. (Unpublished doctoral dissertation). University of Stirling, Scotland.

Glaser, B. G. (1978). Theoretical sensitivity. Mill Valley, CA: Sociology Press. Glaser, B. G., \& Strauss, A. L. (1967). The discovery of grounded theory: Strategies for qualitative research. New York, NY: Aldine de Gruyter. Guest, G., Bunce, A., \& Johnson, L. (2006). How many interviews are 
enough? An experiment with data saturation and variability. Field methods, 18(1), 59-82.

Harris, H. L., Altekruse, M. K., \& Engels, D. W. (2003). Helping freshmen student student-athletes adjust to college life using psychoeducational groups. Journal for Specialists in Group Work, 28, 64-81.

Harrison, C. K., \& Lampman, B. (2001). The image of Paul Robeson: Role model for the student athlete. Rethinking History, 5, 117-130.

Harrison, C. K., \& Lawrence, S. M. (2002). Policy, patriarchy, and progressive: Mindsets of women in intercollegiate sports. Texas Entertainment \& Sports Law Journal, 11(3), 5-13.

Harrison, C. K., \& Lawrence, S. M. (2003). African American student-athletes' perceptions of career transition in sport: A qualitative and visual elicitation. Race Ethnicity and Education, 6, 373-394.

Harrison, C. K., \& Lawrence, S. M. (2004). Female and male student-athletes' perceptions of career transition in sport and higher education: A visual elicitation and qualitative assessment. Journal of Vocational Education \& Training, 56, 485-506.

Huffman, L. T., \& Cooper, C. G. (2012). I'm taking my talents to ...: An examination of hometown socio-economic status on the college-choice factors of football student-student-athletes at a Southeastern university. Journal of Issues in Intercollegiate Athletics, 5, 225246.
Huffman, L., Waller, S., \& Hardin, R. (2016). The sport chaplain's role in the holistic care model for collegiate athletes in the United States. Practical Theology, 9(3), 226-241.

Jacobson, B. H., Sobonya, C., \& Ransome, J. (2001). Nutrition practices and knowledge of college varsity student-athletes: A follow up. Journal of Strength and Conditioning Research, 15, 63-68.

Jones, I., \& Gratton, C. (2015). Research methods for sports studies. ( ${ }^{\text {rd }} \mathrm{ed}$.). New York, NY: Routledge.

Kadlcik, J., \& Flemr, L. (2008). Athletic career termination model in the Czech Republic: A qualitative exploration. International Review for the Sociology of Sport, 43, 251-269.

Kamphoff, C. S. (2010). Bargaining with patriarchy: women's coaches' experience and their decision to leave collegiate coaching. Research Quarterly for Exercise and Sport, 81(3), 360-372.

Kleiber, D., Mannell, R., \& Walker, G. (2011). A social psychology of leisure. State College, PA: Venture Publishing, Inc.

Kilty, K. (2006). Women in coaching. Sport Psychologist, 20(2), 222-234.

Knights, S., Sherry, E., \& Ruddock-Hudson, M. (2015). Investigating elite end-of-athletic-career transition: A systematic review. Journal of Applied Sport Psychology, 28(3), 291-308.

Kvale, S. (1996). Interviews: An introduction to qualitative research interviewing. Thousand Oaks, CA: Sage 
Lally, P. (2007). Identity and athletic retirement: A prospective study. Psychology of Sport and Exercise, 8, 85-99.

Landino, R. (2013). Growth and change through the college years. Retrived from http://psychcentral.com/lib/growthand-change-through-the-collegeyears/.

Lavalle, D., \& Robinson, H. K. (2007). In pursuit of an identity: A qualitative exploration of retirement from women's artistic gymnastics. Psychology of Sport and Exercise, 8(1), 119-141.

Leonard, J. M., \& Schimmel, C. J. (2016). Theory of work adjustment and student-athletes' transition out of sport. Journal of Issues in Intercollegiate Athletics, 9, 62-85.

Lindlof, T. R., \& Taylor, B. C. (2011). Qualitative communication research methods. Los Angeles: Sage.

Lotysz, G. J., \& Short, S. E. (2004). 'What ever happened to...' The effects of career termination from the National Football League. Athletic Insight, 6, 47-66.

Martinus, J. M. (2007). Psychological effects of retirement on elite athletes. (Unpublished doctoral dissertation). Stellenbosch University, South Africa.

McGillivray, D., Fearn, R., \& McIntosch, A. (2005). Caught up in and by the beautiful game: A case study of Scottish professional footballers. Journal of Sport and Social Issues, 29, 102-123.

McKenna, J., \& Thomas, H. (2007). Enduring injustice: A case of retirement from professional rugby union. Sport, Education, and Society, 12, 19-35.
Merriam, S. B. (2009). Qualitative research a guide to design and implementation. San Fransisco, CA: Jossey-Bass.

Muscat, A. C. (2010). Elite athletes' experience of identity changes during a career-ending injury: An interpretative description. (Unpublished doctoral dissertation). University of British Columbia, Vancouver.

Myers, J. E., \& Sweeney, T. J. (2005). The indivisible self: An evidenced-based model of wellness. Journal of Individual Psychology, 61, 269-279.

National Collegiate Athletic Association (2014). NCAA student-athlete substance use study: Executive summary August 2014. Retrieved from http:// www.ncaa.org/about/resources/ research/ncaa-student-athlete-substance-use-study-executive-summary-august-2014

National Collegiate Athletic Association (2016a). Results of the Division I Time Demands Survey. Retrieved from http://www.ncaa.org/sites/ default/files/2016RES_DI-Time-Demands-Full_20160506.PDF

National Collegiate Athletic Association (2016b). Estimated probability of competing in college athletics. Retrieved from http://www.ncaa.org/about/ resources/research/estimated-probability-competing-college-athletics

National Collegiate Athletic Association (2016c). Life skills symposium. Retrieved from http://www.ncaa.org/ about/resources/leadership-development/life-skills-symposium 
National Collegiate Athletic Association (2018). NCAA innovation in research and practice grant program. Retrieved from http://www.ncaa.org/about/resources/research/ncaa-innovations-research-and-practice-grant-program

New, J. (2015). What off-season? Retrieved from https://www.insidehighered.com/news/2015/05/08/ college-student-athletes-say-theydevote-too-much-time-sports-yearround.

Newell, C. P. Q. (2005). Indentification of intrinsic, interpersonal, and contextual factors influencing disengagement from high performance sport. (Doctoral dissertation). Retrieved from ProQuest Dissertations and Theses Database.

Pallarés, S., Azócar, F., Torregrosa, M., Selva, C. \& Ramis, Y. (2011). Athletic career models in water polo and their involvement in the transition into an alternative career. Cultura, Ciencia y Deporte, 6, 93-103.

Park, S., Lavallee, D., \& Tod, D. (2013). Student-athletes career transition out of sport: A systematic review. International Review of Sport and Exercise Psychology, 6(1), 22-53.

Pate, J. R., Stokowski, S. E., \& Hardin, R. (2011). Third time's a charm: The case of Tennessee's four junior football players who endured three different head coaches in three seasons. Journal of Issues in Intercollegiate Athletics, 4, 354-369.

Rodriguez, N. M., DiMarco, N. M., \& Langley, S. (2009). Position of the American Dietetic Association, Dieti- cians of Canada, and the American College of Sport Medicine: Nutrition and athletic performance. Journal of American Dietetic Association, 109, 509527.

Rubin, H., \& Rubin, I. (1995). Qualitative interviewing: The art of hearing data. Thousand Oaks, CA: Sage.

Saldaña, J. (2013). The coding manual for qualitative researchers ( $2^{\text {nd }} \mathrm{ed}$.). Los Angeles, CA: Sage.

Saxe, K., Hardin, R., Taylor, E. A., \& Pate, J. R., (2017). Transition blues: The experience of female collegiate student-athletes. Journal of Higher Education Atbletics and Innovation, 1(2), 25-48.

Schmidt, J., \& Seiler, R. (2003) Identity in high-performance sport: Psychometric investigations with a German Language adaptation of the Athletic Identity Measurement Scale(AIMS-D). Diagnostica, 49(4), 176-183.

Schwenk, T. L., Gorenflo, D. W., Dopp, R. R., \& Hipple, E. (2007). Depression and pain in retired professional football players. Medicine and Science in Sport and Exercise, 39, 599-605.

Shifflett, B., Timm, C., \& Kahanov, L. (2002). Understanding of student-athletes' nutritional needs among student-athletes, coaches, and athletic trainers. Research Quarterly for Exercise and Sport, 73, 357-362.

Shurts, W. M., \& Shoffner, M. F. (2004). Providing career counseling for collegiate student student-athletes: A 
learning theory approach. Journal of Career Development, 31(2), 95-109.

Singer, J. N. (2005). Understanding racism through the eyes of African American male student-athletes. Race, Ethnicity and Education, 8(4), 365-386.

Smith, A. B., Taylor, E. A., \& Hardin, R. (2017). Women and mentoring in collegiate athletic settings. Mentoring \& Tutoring: Partnership in Learning, 25(5), 346-364.

Stankovich, C. E., Meeker, D. J., \& Henderson, J. L. (2001). The positive transitions model for sport retirement. Journal of College Counseling, 4, 81-84.

Strauss, A. L. (1987). Qualitative analysis for social scientists. Cambridge: Cambridge University Press.

Strauss, A., \& Corbin, J. (1998). Basics in qualitative research: Techniques and procedures for developing grounded theory ( $2^{\text {nd }}$ ed.). Thousand Oaks, CA: Sage.

Stronach, M., \& Adair, D. (2010). Lords of the square ring: Future capital and career transition issues for elite indigenous Australian boxers. Cosmopolitan Civil Societies Journal, 2, 46-70.

Taylor, E. A., \& Hardin, R. (2016). Female NCAA Division I athletic directors: Experiences and challenges. Women in Sport \& Physical Activity Journal, 24(1), 14-25.

Taylor, E. A., Ward, R. M., \& Hardin, R. (2017). Examination of drinking habits and motives among collegiate student-student-athletes. Journal of Applied Sport Management, 9(1), 56-82.

Taylor, K. T., \& Pompa, J. (1990). An examination of the relationships among career decision-making self-efficacy, career salience, locus of control, and vocational indecision. Journal of Vocational Behavior, 37, 1731.

Torregrosa, M., Ramis, Y., Pallarés, S., Azócar, F., \& Selva, C. (2015). Olympic athletes back to retirement: A qualitative longitudinal study. Psychology of Sport and Exercise, 21, 50-56.

USOC. (2012). Athlete career, education, and life skills working group. (pp. 1-26).

Warriner, K., \& Lavallee, D. (2008). The retirement experiences of elite gymnasts: Self identity and the physical self. Journal of Applied Sport Psychology, 20, 301-317.

Watson, J. C. (2003). The effects of athletic participation and expectations about counseling on the attitudes toward help seeking behavior among college students. Unpublished doctoral dissertation. University of North Carolina, Greensboro. Watson, J. C., \& Kissinger, D. B. (2007). Athletic participation and wellness: Implications for counseling college student-student-athletes. Journal of College Counseling, 10(2), 153-162.

Wippert, P., \& Wippert, J. (2008). Perceived stress and prevalence of traumatic stress symptoms following athletic career termination. Journal of Clinical Sport Psychology, 2, 1-16.

Wylleman, P., Alfermann, D., \& Lavallee, D. (2004). Career transition in sport: European perspectives. Psychology of Sport and Exercise, 5, 7-20.

Wylleman, P., Rosier, N., \& De Knop, P. (2015). Transitional challenges and 
elite athletes' mental health. In J. Bak- Young, J. A., Pearce, A. J., Kane, R., \& er, P. Safai, \& J. Fraser-Thomas (Eds.), $\quad$ Pain, M. (2006). Leaving the proHealth and elite sport. Is high performance sport a bealthy pursuit? (pp. 99-116). Oxon, UK: Routledge. fessional tennis circuit: Exploratory study of experiences and reactions from elite female athletes. British Journal of Sport Medicine, 40, 477-483. 